\title{
PEMETAAN HABITAT BENTIK BERBASIS OBJEK MENGGUNAKAN CITRA SENTINEL-2 DI PERAIRAN PULAU WANGI-WANGI KABUPATEN WAKATOBI
}

\section{OBJECT BASED MAPPING ON BENTHIC HABITAT USING SENTINEL-2 IMAGERY OF THE WANGI-WANGI ISLAND WATERS OF THE WAKATOBI DISTRICT}

\author{
La Ode Khairum Mastu ${ }^{\text {* }}$, Bisman Nababan ${ }^{2}$, dan James P. Panjaitan ${ }^{2}$ \\ ${ }^{1}$ Program Studi Teknologi Kelautan, Sekolah Pascasarjana, IPB, Bogor \\ ${ }^{2}$ Departemen Ilmu dan Teknologi Kelautan, FPIK-IPB, Bogor \\ *E-mail: khairum_14@apps.ipb.ac.id
}

\begin{abstract}
Research on benthic habitat mapping in the Wangi-wangi Island waters was very limited. Therefore the spatial data availability of benthic habitat in this area is also very limited. The purposes of this study were to map the shallow water benthic habitats using Sentinel-2 image based on object-based classification method (OBIA) and to calculate the accuracy level of benthic habitat classification results in the Wangi-wangi Island waters of the Wakatobi District. This research was conducted in the Wangi-wangi Island waters around Sombu Dive waters and it's surroundings. The study used satellite Sentinel-2 data with $10 \times 10 \mathrm{~m}^{2}$ spatial resolution acquired on 4 April 2017 and the field data were acquired in March - April 2017. Satellite image was classified with OBIA method using contextual editing at level 1. At level 2, we used supervised classification with some algorithms such as support vector machine (SVM), decision tree (DT), Bayesian, and k-nearest neighbour (KNN) with input themathic layer from field data. The classification of benthic habitats was performed in 12 and 9 classes with the application of segmentation-optimization scale of 1, 1.5, 2, and 2.5. Based on OBIA method, benthic habitat can be mapped with the best overall accuracy of $60.4 \%$ and $64.1 \%$ for the image classification of 12 and 9 classes, respectively with SVM algorithm and the optimum segmentation scale of 2 .
\end{abstract}

Keywords: mapping, benthic habitats, OBIA, Sentinel-2, Wangi-wangi Island waters

\begin{abstract}
ABSTRAK
Penelitian pemetaan habitat bentik di Pulau Wangi-wangi masih sangat sedikit dilakukan, sehingga ketersediaan data spasial habitat bentik di daerah ini sangat terbatas. Penelitian ini bertujuan untuk memetakan habitat bentik perairan dangkal menggunakan citra Sentinel-2 dengan metode klasifikasi berbasis objek/OBIA dan menghitung tingkat akurasi hasil klasifikasi habitat bentik di perairan Pulau Wangi-wangi Kabupaten Wakatobi. Penelitian ini dilaksanakan di perairan Pulau Wangi-wangi, khususnya perairan Sombu Dive dan sekitarnya. Penelitian ini menggunakan data satelit Sentinel-2 dengan resolusi spasial $10 \times 10 \mathrm{~m}^{2}$ yang diakuisisi pada tanggal 4 April 2017 dan pengambilan data lapangan dilakukan pada bulan Maret - April 2017. Klasifikasi citra dengan metode OBIA menggunakan metode contextual editing pada level 1. Level 2 menggunakan klasifikasi terbimbing dengan beberapa algoritma klasifikasi yaitu support vector machine (SVM), decision tree (DT), Bayesian, dan k-nearest neighbour (KNN) dengan input themathic layer dari data lapangan. Klasifikasi habitat bentik dilakukan pada 12 dan 9 kelas dengan penerapan optimasi skala segmentasi yaitu 1, 1,5, 2, dan 2,5. Berdasarkan metode OBIA, habitat bentik dapat dipetakan dengan tingkat akurasi sebesar $60,4 \%$ dan $64,1 \%$ pada citra klasifikasi 12 dan 9 kelas secara berturut-turut pada nilai optimum skala segmentasi 2 dengan algoritma SVM.
\end{abstract}

Kata kunci: pemetaan, habitat bentik, OBIA, Sentinel-2, perairan pulau Wangi-wangi 


\section{PENDAHULUAN}

Perairan Kepulauan Wakatobi berada pada wilayah "Coral Triangle" atau wilayah pusat segitiga terumbu karang dunia yang memiliki keanekaragaman terumbu karang dan hayati tertinggi di dunia (Supriatna, 2008; BTNW, 2009; Wilson et al., 2012; Purbani et al., 2014). Wakatobi tersusun dari gugusan pulau-pulau dengan empat pulau besar yaitu pulau Wangi-Wangi, Kaledupa, Tomia, dan Binongko (COREMAP, 2001; Suyarso dan Budiyanto, 2008). Habitat bentik di Wakatobi memiliki kompleksitas yang sangat tinggi dimana keanekaragaman terumbu karang dan lamun yang dijadikan sebagai tempat hidup bagi berbagai jenis biota laut. Habitat bentik merupakan tempat hidup dari berbagai jenis organisme yang disusun oleh rumput laut, lamun, alga, karang hidup, karang mati dengan tipe substrat seperti pasir, lumpur, dan pecahan karang (Zhang et al., 2013; Anggoro, 2015).

Pemanfaatan teknologi satelit penginderaan jauh dalam menyediakan informasi secara spasial telah banyak dilakukan dan sampai saat ini terus mengalami kemajuan. Penelitian terkait pemanfaatan teknologi penginderaan jauh khususnya pada penyediaan informasi spasial habitat bentik perairan dangkal telah banyak dilakukan (Siregar, 2010; Phinn et al., 2011; Selamat et al., 2012a; Selamat et al., 2012b; Siregar et al., 2013; Zhang et al., 2013; Anggoro et al., 2015; Wahidin et al., 2015; Zhang, 2014). Beberapa pemetaan habitat bentik di wilayah perairan Wakatobi telah dilakukan terkait dengan pemetaan luasan, distribusi spasial maupun geomorfologi terumbu karang (COREMAP, 2001; Adji, 2014; Yulius et al., 2015; Hafizt et al., 2017). Pemetaan habitat bentik, dalam penerapannya masih terdapat permasalahan yaitu adanya pengaruh permukaan perairan dan kedalaman perairan terhadap reflektansi dasar perairan (Lyzenga, 1981). Permasalahan lain adalah penentuan metode klasifikasi citra dengan tingkat akurasi yang baik dari peta yang dihasilkan
(Green et al., 2000; Congalton and Green, 2009). Khusus untuk perairan di sekitar pulau Wangi-wangi, penelitian terkait pemetaan habitat bentik masih sangat sedikit dilakukan.

Teknologi penginderaan jauh yang berkembang sampai saat ini, tidak telepas dari semakin berkembangnya teknologi satelit yang diluncurkan, dalam hal ini satelit sumber daya alam. Teknologi satelit berkembang dengan berbagai kemampuan dalam menyediakan data citra terkait dengan informasi permukaan bumi. Citra satelit yang dihasilkan bervariasi mulai dari citra dengan resolusi spasial dan resolusi spektral yang rendah hingga tinggi. Citra satelit yang tersedia juga ada yang gratis dan berbayar. Berbagai macam jenis citra satelit yang berkembang sampai saat ini salah satunya yaitu citra satelit Sentinel-2. Citra satelit Sentinel-2, saat ini menjadi alternatif baru dalam menyediakan informasi permukaan bumi karena selain mudah didapatkan dan gratis, citra Sentinel-2 menawarkan kualitas data citra dengan resolusi spasial yang lebih baik yaitu $10 \times 10 \mathrm{~m}^{2} /$ piksel, dibandingan dengan citra open source lainnya yang sering digunakan seperti citra Landsat yang hanya memiliki resolusi spasial $30 \times 30 \mathrm{~m}^{2} /$ piksel.

Pemanfaatan citra satelit untuk memetakan habitat dasar perairan dangkal tentu tidak terlepas dari proses klasifikasi ataupun analisis digital dari citra tersebut. Analisis digital data penginderaan jauh secara umum memiliki dua pendekatan yaitu berbasis piksel (pixel-based) dan berbasis objek (object-based). Penggunaan metode klasifikasi berbasis objek saat ini menjadi alternatif dalam mengklasifikasikan suatu objek permukaan bumi. Klasifikasi berbasis objek/ Objek-Based Image Analysis (OBIA) merupakan salah satu sub-kajian dari GISscience yang fokus pada pengembangan metode analisis citra penginderaan jauh berbasis objek sehingga menjadi beberapa objek yang memiliki kesamaan tertentu (Navulur, 2007). Penggunaan metode OBIA telah terbukti dapat meningkatkan akurasi 
pemetaan habitat bentik, geomorfologi dan ekologi ekosistem terumbu karang pada citra resolusi spasial sedang hingga resolusi spasial tinggi (Phinn et al., 2011; Anggoro et al., 2015; Wahidin et al., 2015).

Pemetaan habitat bentik di perairan wakatobi telah dilakukan, namun rata-rata masih terbatas pada pemetaan luasan, distribusi maupun geomorfologi terumbu karang. Pemetaan habitat bentik Di Wakatobi telah dilakukan oleh Hafizt et al. (2017) dengan memetakan habitat bentik di perairan pulau Lentea Kabupaten Wakatobi menggunakan model depth invariant index (DII) dan relative water depth index (RWDI) dan proses klasifikasi habitat bentik menggunakann metode ISO-DATA yang tergolong dalam unsupervised classification yang dilakukan terpisah pada habitat bentik perairan dangkal dan perairan dalam sehingga menghasilkan akurasi keseluruhan tertinggi sebesar $83,93 \%$ pada 7 kelas habitat bentik.

Penelitian terkait pemetaan habitat bentik khususnya di perairan Pulau Wangiwangi baru pertama kali dilakukan oleh Yulius et al. (2015) terkait distribusi spasial terumbu karang, sehingga ketersediaan data spasial habitat bentik di daerah ini sangat terbatas. Pemanfaatan data citra satelit dapat dijadikan sebagai alternatif utama dalam menyediakan data dan informasi spasial secara efektif dan efisien pada area yang luas dibandingkan pemetaan konvensional dengan pengamatan langsung di lapangan. Berdasarkan hal tersebut, sehingga perlu dilakukan penelitian terkait pemetaan habitat bentik dengan penerapan metode OBIA di lokasi penelitian dengan jumlah tipe habitat bentik yang lebih banyak atau detail. Selain itu dengan penerapan metode OBIA pada citra Sentinel-2 diharapkan dapat mengkalifikasikan habitat bentik khususnya pada kompleksitas habitat yang tinggi dengan baik.

Tujuan penelitian ini adalah untuk memetakan habitat bentik perairan dangkal menggunakan citra Sentinel-2 dengan metode klasifikasi berbasis objek/OBIA dan menggunakan beberapa algoritma klasifikasi (machine learning) pada jumlah kelas habitat bentik yang lebih banyak atau lebih detail, serta menghitung tingkat akurasi hasil klasifikasi habitat bentik di perairan Pulau Wangi-wangi Kabupaten Wakatobi.

\section{METODE PENELITIAN}

\subsection{Waktu dan Lokasi}

Penelitian ini dilaksanakan pada bulan Maret-April 2017, bertempat di perairan Pulau Wangi-wangi, khususnya perairan Sombu Dive dan sekitarnya, Kabupaten Wakatobi Provinsi Sulawesi Tenggara (Gambar 1). Secara geografis lokasi penelitian terletak antara $5^{\circ} 15^{\prime} 22.6^{\prime \prime}$ $5^{\circ} 16^{\prime} 33.3^{\prime \prime}$ LS dan $123^{\circ} 31^{\prime} 11.5^{\prime \prime}$ $123^{\circ} 31^{\prime} 14.9^{\prime \prime} \mathrm{BT}$.

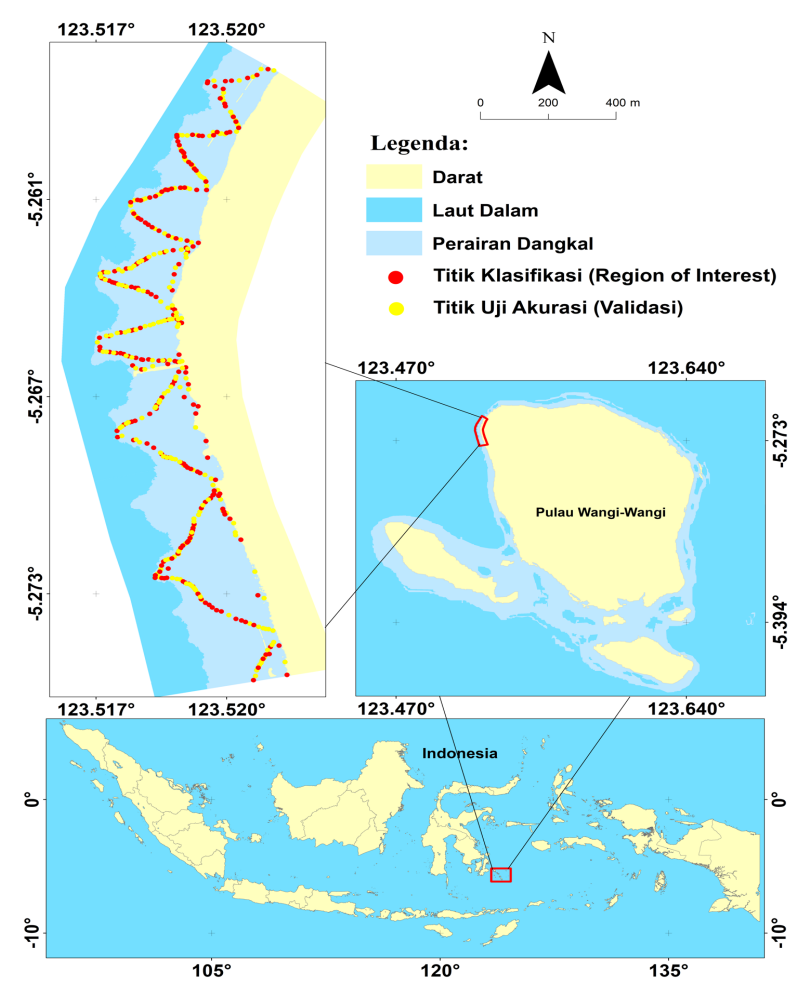

Gambar 1. Peta lokasi penelitian; Titik warna merah menunjukkan lokasi sampling untuk tujuan klasifikasi dan titik warna kuning menunjukkan lokasi sampling untuk uji akurasi. 


\subsection{Data}

Data yang digunakan pada penelitian ini adalah data citra satelit multispektral Sentinel-2. Citra Sentinel-2 diperoleh secara gratis yang dapat diunduh secara langsung pada website ESA Copernicus (https://scihub.copernicus.eu/dhus/\#/home).

Citra satelit Sentinel-2 diakuisisi pada tanggal 4 April 2017 pada lembar perekaman 51MWQ. Citra Sentinel-2 yang diunduh merupakan data Level $1 \mathrm{C}$, yang artinya data citra tersebut telah terkoreksi secara geometrik dan radiometrik. Citra Sentinel-2 memiliki 13 sensor dengan resolusi spasial yang berbeda-beda. Sensor atau band yang digunakan dalam penelitian ini adalah band sinar tampak (visible) dan infrared dengan resolusi spasial 10 meter yaitu band 2 (blue), band 3 (green), band 4 (red) dan band 8 (NIR).

Pengumpulan data habitat bentik di lapangan dilakukan dengan pengamatan langsung secara visual dan dikombinasikan dengan menggunakan teknik foto transek kuadrat (Roelfsema and Phinn, 2008; Siregar, 2010; Phinn et al., 2011). Transek kuadrat yang digunakan dalam penelitian ini berukuran $50 \times 50 \mathrm{~cm}^{2}$ dengan titik-titik sampling seperti terlihat pada Gambar 1. Luasan transek kuadrat yang digunakan merupakan penyesuaian terhadap akurasi dari GPS (global positioning system) yang digunakan yaitu GPS Trimbel GeoExplorer 6000 series dengan akurasi $50 \mathrm{~cm}$. Transek kuadrat dengan luasan tersebut juga berfungsi untuk mempermudah dalam mengidentifikasi atau menentukan komponen habitat bentik dominan secara visual baik secara langsung di lapangan maupun pada hasil foto transek. Pengambilan data habitat bentik dilakukan dengan meletakkan transek kuadrat pada area habitat bentik yang dominan atau homogen, dengan tujuan untuk memaksimalkan keterwakilan terhadap ukuran dari resolusi spasial citra yang digunakan. Selanjutnya dilakukan pengambilan titik koordinat dengan menggunakan GPS disetiap lokasi pengumpulan data.
Komponen habitat bentik yang didapatkan akan digunakan sebagai dasar dari pembentukan skema klasifikasi habitat bentik di lokasi studi. Data habitat bentik yang diambil sebanyak 434 titik pengamatan, kemudian dibagi menjadi dua bagian yaitu; (1) sebanyak 217 titik sebagai acuan untuk RoI (region of interest) pada proses klasifikasi citra dan (2) sebanyak 217 titik akan dijadikan sebagai data untuk uji akurasi dari hasil klasifikasi citra.

\subsection{Skema Klasifikasi}

Skema klasifikasi habitat bentik yang digunakan pada penelitian ini yaitu ditentukan berdasarkan hasil pengamatan habitat bentik yang dilakukan secara langsung maupun menggunakan bantuan foto transek kuadrat pada setiap titik pengamatan di lokasi penelitian. Pembuatan skema klasifikasi daerah pengamatan dilakukan dengan mengacu pada prinsip tutupan habitat bentik dominan (Siregar, 2010). Penentuan komponen habitat bentik dominan dilakukan dengan analisis visual secara langsung di lapangan maupun hasil foto transek kuadrat disetiap komposisi habitat bentik yang terdapat di dalam transek kuadrat pada titik pengamatan. Deskripsi atau penamaan dari habitat bentik nantinya ditentukan berdasarkan komposisi tutupan habitat bentik dominan yang seluruhnya dibangun oleh satu atau beberapa komponen habitat bentik perairan dangkal. Skema kalasifikasi yang dibuat pada penelitian ini disusun secara terstrukrur yang terdiri dari 2 level skema klasifikasi yaitu skema klasifikasi level 1 (kelas reef level) dan skema klasifikasi level 2 (kelas habitat bentik).

\subsection{Koreksi Kolom Perairan}

Koreksi kolom perairan mampu mengurangi pengaruh attenuation dimana intensitas cahaya matahari secara ekponensial akan berkurang dengan meningkatnya kedalaman perairan. Lyzenga (1978; 1981) mengemukakan bahwa teknik koreksi kolom perairan merupakan pendekatan sederhana 
berbasis citra untuk mengkompensasi pengaruh variabel kedalaman dalam pemetaan dasar perairan. Koreksi kolom perairan menggunakan komposisi band sinar tampak dengan mengekstrak nilai piksel citra pada tipe subtrat yang sama (homogen) dalam hal ini substrat pasir dari kedalaman berbeda (Green et al., 2000; Wahiddin et al., 2014). Pasangan band yang digunakan pada penelitian ini adalah band sinar tampak citra Sentinel-2 yaitu band 2 (blue), band 3 (green), band 4 (red). Metode koreksi kolom perairan ini menghasilkan Depth Invariant Index (DII) dari setiap pasangan band spektral dengan persamaan berikut (Green $e t$ al., 2000).

$$
\mathrm{DII}_{\mathrm{ij}}=\log \left(x_{i}\right)-\left[(K i / K j) * \log \left(x_{j}\right)\right]
$$

dimana,

$$
\begin{aligned}
& K i / K j=a+\sqrt{a^{2}+1} \\
& a=\frac{\sigma i i-\sigma j j}{2_{\sigma i j}} \ldots \ldots \ldots \ldots
\end{aligned}
$$

Keterangan: $\mathrm{Ki} / \mathrm{Kj}$ adalah koefisien attenuation, $\sigma i i$ adalah variance band $i, \sigma j j$ adalah variance band $j$ dan $\sigma i j$ adalah covariance pasangan band $i$ dan $j$.

Koreksi kolom perairan digunakan dengan menghitung DII yang menggunakan informasi dari rasio koefisien atenuasi tiap pasangan band sinar tampak. Berdasarkan band sinar tampak yang digunakan pada penelitian ini, maka diperoleh tiga pasangan band dengan komposisi pasangan band yaitu DII 2/3 (biru-hijau), DII 2/4 (biru-merah), dan DII 3/4 (hijau-merah). Hasil perhitungan rasio ki/kj disajikan pada Tabel 1.

Tabel 1. Rasio koefisien atenuasi pasangan band sinar tampak citra Sentinel-2.

\begin{tabular}{lc}
\hline \multicolumn{1}{c}{$\begin{array}{c}\text { Pasangan } \\
\text { Band }\end{array}$} & $\begin{array}{c}\text { Koefisien Atenuasi } \\
(\mathrm{ki} / \mathrm{kj})\end{array}$ \\
\hline 2/3 (biru - hijau) & 0,67 \\
2/4 (biru - merah) & 0,30 \\
3/4 (hijau - merah) & 0,49 \\
\hline
\end{tabular}

Perhitungan koefisien atenuasi $(\mathrm{ki} / \mathrm{kj})$ dari beberapa pasangan band sinar tampak diperoleh koefisien atenuasi berkisar antara 0,30-0,67. Kisaran koefisien atenuasi yang dihasilkan tersebut masih tergolong dalam kisaran atenuasi perairan laut (Lyzenga 1981). Tiga pasangan band DII yang dihasilkan dari citra Sentinel-2 selanjutnya akan digunakan sebagai input data feature dalam proses klasifikasi habitat bentik perairan dangkal berbasis objek.

\subsection{Klasifikasi Citra}

Klasifikasi citra yang digunakan untuk memetakan habitat bentik yaitu menggunakan klasifikasi citra berbasis objek/ OBIA. Metode OBIA merupakan metode klasifikasi yang dikembangkan dengan proses segmentasi dan analisis objek atau proses klasifikasi citra berdasarkan karakteristik spasial, spektral dan skala temporalnya, sehingga menghasilkan objek citra atau segmen-segmen yang selanjutnya digunakan untuk klasifikasi (Wang et al., 2004; Blaschke, 2010). Secara umum tahapan penggunaan metode OBIA dibagi atas dua yaitu; (1) diawali dengan proses segmentasi citra, dan (2) citra yang telah disegmentasi kemudian diklasifikasikan berdasarkan kelas-kelas yang telah ditentukan sebelumnya.

\subsubsection{Segmentasi}

Segmentasi merupakan konsep untuk membangun objek atau segmen dari pikselpiksel menjadi objek atau segmen yang sama (Navulur, 2007). Penelitian ini algoritma segmentasi yang digunakan yaitu algoritma multiresolution segmentation (MRS). Proses segmentasi dengan algoritma MRS terdapat tiga perameter penting yaitu shape (bentuk), compactness (kekompakan), dan scale (skala/ukuran). Penerapan segmentasi multiskala dengan menggunakan beberapa skala yang berbeda-beda pada level 1 (reef level) dan level 2 (habitat bentik). Pada level 1 nilai skala yang digunakan yaitu 5. Sedangkan pada level 2 akan dilakukan optimasi skala 
segmentasi pada beberapa nilai skala yang berbeda yaitu MRS 1, 1,5, 2, dan 2,5. Pada tahap segmentasi, nilai parameter shape dan compactness menggunakan nilai tetap yaitu masing-masing 0,1 dan 0,5 . Sampai saat ini tidak ada ketentuan baku mengenai standar nilai parameter dalam klasifikasi berbasis objek (Benfield et al., 2007; Phinn et al., 2011; Trimble, 2014).

\subsubsection{Klasifikasi Multiskala}

Konsep klasifikasi multiskala yang dibangun dalam penelitian ini terdiri dari 2 level objek citra yaitu level 1 (reef level) dan level 2 (habitat bentik). Klasifikasi citra pada tiap level yaitu dengan menggunakan beberapa algoritma. Algoritma ini digunakan untuk membangun suatu aturan (rule set) pada pohon proses (process tree) yang penggunaannya disesuaikan dengan kebutuhan pengguna. Rule set merupakan suatu kumpulan dari beberapa algoritma yang digunakan dalam mengklasifikasikan objek kedalam kelas-kelas tertentu (Anggoro, 2015; Anggoro et al., 2017).

Klasifikasi citra dengan multiskala menggunakan metode contextual editing pada level 1 dan klasifikasi terbimbing menggunakan beberapa algoritma machine learning pada level 2. Klasifikasi pada level 1 yaitu menggunakan assign class dengan penerapan batasan nilai (threshold) tertentu sehingga menghasilkan kelas objek sesuai dengan apa yang diinginkan. Nilai threshold diperoleh melalui try and error untuk menemukan nilai optimun.

Klasifikasi level 2 yaitu menggunakan classifier dengan penerapan beberapa algoritma klasifikasi seperti support vector machine (SVM), decision tree (DT), Bayesian dan k-nearest neighbour (KNN) dengan input themathic layer atau training area dari data lapangan untuk mengklasifikasikan kelas habitat bentik. Formula dari masing-masing algoritma klasifikasi yang digunakan yaitu sebagai berikut:
SVM (Tzotsos, 2006):

$f(x)=\sum_{i \in S} \lambda_{i} y_{i} K\left(x_{i} x\right)+w_{0}$

Keterangan: $K$ merupakan fungsi kernel, $y_{i}$ dan $x_{i}$ mewakili sampel pelatihan, $\lambda_{i}$ merupakan pengganda Lagrange, $S$ bagian dari sampel pelatihan yang sesuai dengan pengganda Lagrange non-zero, dan $w_{0}$ adalah parameter hyperplane.

Bayes (Han et al., 2012):

$P\left(C_{i} \mid X\right)=\frac{P\left(C_{i} \mid X\right) P\left(C_{i}\right)}{P(X)}$

Keterangan: $X$ merupakan kriteria suatu kasus berdasarkan masukan, $C i$ kelas solusi pola ke- $i$, dimana $i$ adalah jumlah label kelas, $P(C i \mid X)$ probabilitas kemunculan label kelas $C i$ dengan kriteria masukan $X, P(X \mid C i)$ probabilitas kriteria masukan $X$ dengan label kelas $C i, P(C i)$ probabilitas label kelas $C i$.

KNN (Wei et al., 2005):

$d=\sqrt{\sum_{f}\left[\frac{v_{f}^{(s)}-v_{f}^{(o)}}{\sigma_{f}}\right]^{2}}$

Keterangan: $d$ merupakan jarak antara objek sampel $s$ dan objek gambar $o, v_{f}^{(s)}$ nilai fitur objek sampel untuk fitur $f, v_{f}^{(o)}$ nilai fitur objek gambar untuk fitur $f, \sigma_{f}$ standar deviasi dari nilai fitur untuk fitur $f$.

- DT (Bradski and Kaehler, 2008):

Gini impurity: $i(N)=\sum_{j \neq i} P\left(\omega_{i}\right) P\left(\omega_{j}\right) \ldots \ldots$

Keterangan: metode ini menggunakan notasi $P\left(\omega_{j}\right)$ untuk menunjukkan fraksi pola pada node $N$ yang berada di kelas $\omega_{j}$.

\subsection{Uji Akurasi}

Pengujian akurasi dilakukan terhadap seluruh citra hasil klasifikasi untuk mengetahui akurasi dari teknik klasifikasi yang 
diterapkan. Uji akurasi yang umum dilakukan pada data hasil klasifikasi penginderaan jauh adalah matriks kesalahan/ confusion matrix (Tabel 2). Hal ini dilakukan dengan membandingkan citra hasil klasifikasi terhadap kelas atau objek sebenarnya yang diperoleh berdasarkan pengamatan di lapangan (Wahiddin, 2015). Uji akurasi mengacu pada Congalton and Green (2009) yang terdiri dari overall accuracy (OA), producer (PA) dan user accuracy (UA) dan menggunakan beberapa persamaan untuk menghitung tingkat akurasi baik itu OA, PA, dan UA masing-masing disajikan pada persamaan berikut.

$O A=\frac{\sum_{i=1}^{k} n i i}{n}$

$P A=\frac{n j j}{n+j}$

$U A=\frac{n i i}{n i+}$

Keterangan: $\mathrm{k}$ adalah jumlah baris pada matriks, $\mathrm{n}$ adalah jumlah pengamatan, $n_{i i}$ adalah jumlah pengamatan pada kolom ke-i dan baris ke-i dan $n_{j j}$ merupakan jumlah pengamatan pada kolom ke-j dan baris ke-j.

Secara umum prosedur penelitian yang telah dilakukan disajikan pada Gambar 2.

Tabel 2. Confusion matrix (matriks kesalahan).

\begin{tabular}{ccccc}
\hline & \multicolumn{3}{c}{ Lapangan $(\mathrm{j})$} & Jumlah baris $\mathrm{n}_{\mathrm{i}+}$ \\
\hline & $\mathrm{n}_{11}$ & $\mathrm{n}_{12}$ & $\mathrm{n}_{1 \mathrm{k}}$ & $\mathrm{n}_{1+}$ \\
\hline Jumlah Kolom $\mathrm{n}_{+\mathrm{j}}$ & $\mathrm{n}_{21}$ & $\mathrm{n}_{22}$ & $\mathrm{n}_{2 \mathrm{k}}$ & $\mathrm{n}_{2+}$ \\
\hline & $\mathrm{n}_{\mathrm{k} 1}$ & $\mathrm{n}_{\mathrm{k} 2}$ & $\mathrm{n}_{\mathrm{kk}}$ & $\mathrm{n}_{\mathrm{k}+}$ \\
\hline
\end{tabular}

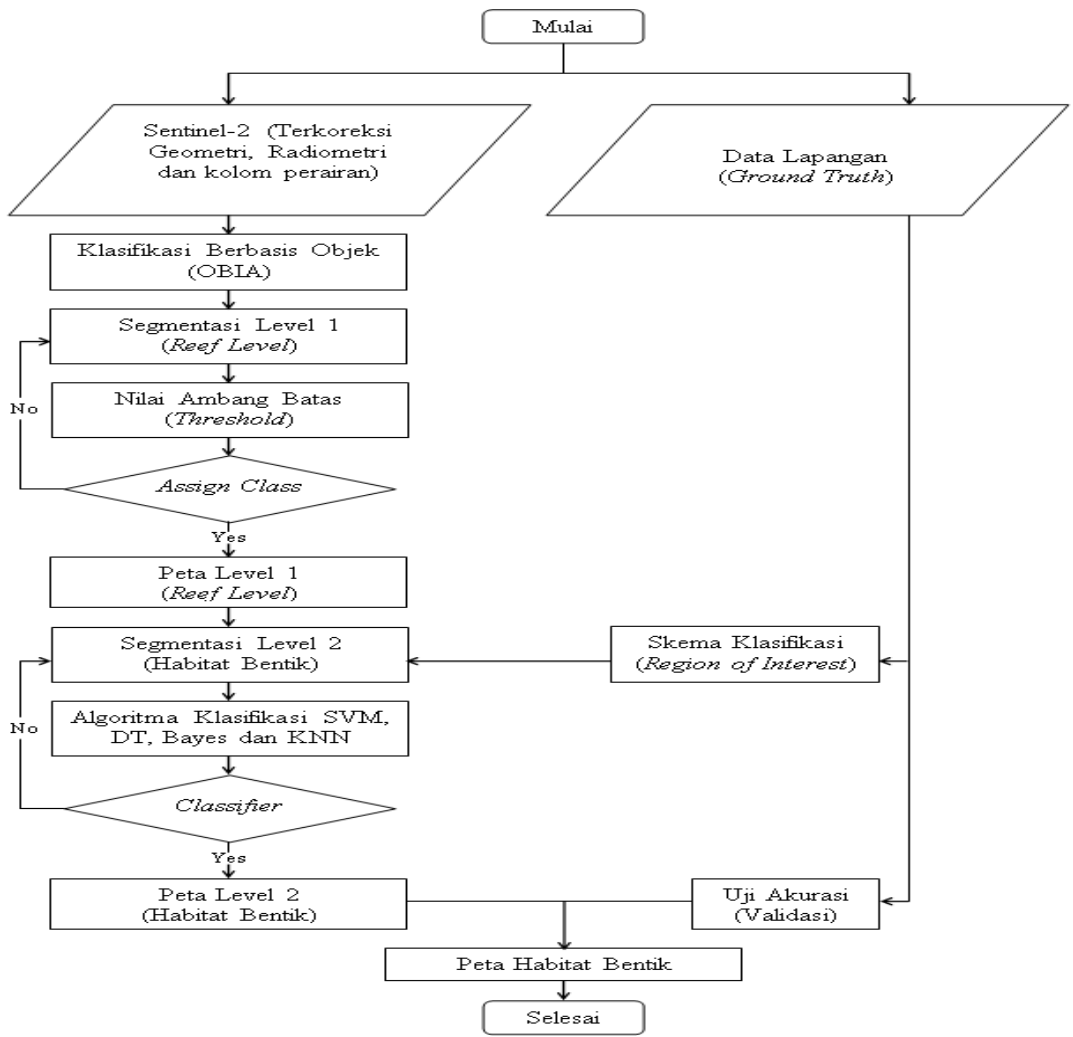

Gambar 2. Diagram alir penelitian. 


\section{HASIL DAN PEMBAHASAN}

\subsection{Skema Klasifikasi}

Berdasaarkan hasil pengamatan di lapangan pada 434 titik stasiun pengamatan diperoleh komponen habitat bentik perairan dangkal di lokasi penelitian sebanyak 12 komponen habitat bentik. Dari hasil tersebut, kemudian pada penelitian ini dibangun 2 skema klasifikasi habitat bentik yaitu 12 dan 9 kelas habitat bentik perairan dangkal. Duabelas kelas habitat bentik yang dihasilkan yaitu Alga (A), Batu intertidal (BI), Karang hidup (KH), Karang hidup+Karang mati (KHKM), Karang mati (KM), Lamun (L), Lamun+Pasir (LP), Pasir (P), Pasir+Lamun (PL), Pasir+Rubble (PR), Rubble (R) dan Rubble+Lamun (RL). Sedangkan 9 kelas habitat bentik yang terbentuk yaitu terdiri dari Alga (A), Batu intertidal (BI), Karang hidup (KH), Karang mati (KM), Lamun (L), Lamun+Pasir (LP), Pasir (P), Pasir+Lamun (PL), dan Rubble (R).

Penentuan skema klasifikasi habitat bentik sampai saat ini tidak mempunyai ketentuan atau standarisasi yang baku, sehingga penamaan kelas habitat bentik dalam penelitian ini disesuaikan dengan komposisi penyusun habitat bentik dominan yang teramati di lapangan. Beberapa penelitian tentang penentuan skema klasifikasi habitat bentik perairan dangkal telah banyak dilakukan dan menghasilkan skema klasifikasi atau jumlah kelas yang berbeda-beda seperti skema klasifikasi yang dikembangkan secara hirarki oleh Phinn et al. (2011) menghasilkan 12 kelas habitat bentik. Zhang et al. (2013) menghasilkan 12 kelas habitat bentik, Siregar et al. (2013) menghasilkan 6 habitat bentik, Wahiddin et al. (2015) menghasilkan 7 kelas habitat bentik serta Anggoro et al. (2017) menghasilkan 9 skema klasifikasi habitat bentik.

Skema klasifikasi yang dihasilkan pada penelitian ini terdiri dari 2 level skema klasifikasi. Skema klasifikasi level 1 (reef level) terdiri dari 3 kelas yaitu kelas darat, perairan dangkal dan kelas laut dalam, sedangkan skema klasifikasi level 2 (habitat bentik) terdiri dari 12 dan 9 kelas habitat bentik perairan dangkal. Skema klasifikasi habitat bentik perairan dangkal yang dihasilkan dari 434 titik stasiun pengamatan, selanjutnya akan dibagi menjadi dua yaitu sebanyak 217 stasiun pengamatan akan digunakan sebagai data RoI (region of interest) pada proses klasifikasi citra, kemudian sisahnya sebanyak 217 stasiun pengamatan akan dijadikan sebagai data untuk uji akurasi dari hasil klasifikasi citra.

\subsection{Klasifikasi Citra \\ 3.2.1. Segmentasi}

Dasar dalam proses klasifikasi citra berbasis objek yaitu segmentasi. Pada level 1 skala segmentasi yang digunakan yaitu 5 dengan menghasilkan sebanyak 506 segmen/ objek. Pada level 2 proses segmentasi dilakukan dengan optimasi skala segmentasi yaitu dengan penerapan beberapa skala segmentasi yang berbeda. Optimasi skala segmentasi yang digunakan adalah MRS 1, 1,5, 2, dan 2,5. Hasil segmentasi citra dengan optimasi beberapa skala segmentasi dapat dilihat pada Gambar 3.

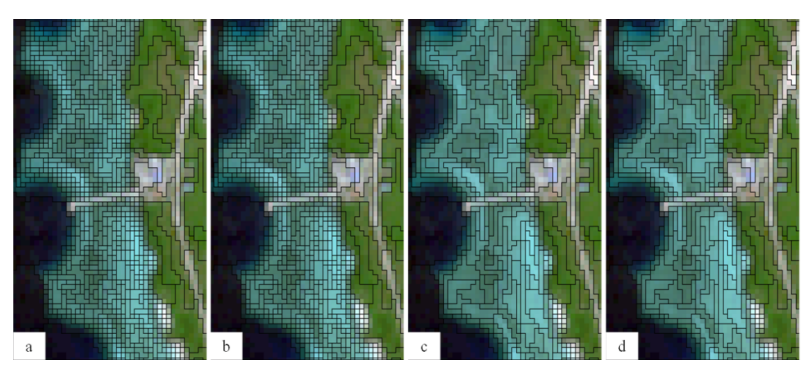

Gambar 3. Variasi ukuran objek hasil optimasi pada citra Sentinel-2; Skala segmentasi (a) 1, (b) 1,5, (c) 2, dan (d) 2,5.

Berdasarkan hasil segmentasi Gambar 3 dengan optimasi skala segmentasi $(1,1,5$, 2, dan 2,5) pada level 2 dihasilkan jumlah objek masing-masing sebanyak 3067, 1896, 1327, dan 1027. Hasil tersebut, diperoleh bahwa semakin kecil skala segmentasi yang diterapkan, maka jumlah objek yang 
dihasilkan akan semakin banyak dan juga menghasilkan bentuk atau ukuran objek yang semakin kecil. Objek yang dihasilkan melalui proses segmentasi pada penelitian ini, selanjutnya akan diklasifikasikan berdasarkan data skema klasifikasi yang telah dibuat sebelumnya.

\subsubsection{Klasifiasi Reef Level (Level 1)}

Klasifikasi level 1 pada penelitian ini menghasilkan 3 kelas yaitu darat, perairan dangkal, dan perairan dalam (Gambar 4). Kelas perairan dangkal menjadi batas area kajian habitat bentik dan selanjutnya akan disegmentasi ulang pada tahap klasifikasi habitat bentik (level 2). Phinn et al. (2011) dan Anggoro et al. (2017) mengungkapkan bahwa pada sistem klasifikasi hirarki hasil klasifikasi level 1 (reef level) yaitu pada kelas perairan dangkal menjadi batasan area kajian dan diproses menjadi segmen baru untuk klasifikasi pada level berikutnya, dalam hal ini yaitu level 2 (habitat bentik). Berdasarkan hasil klasifikasi level 1 diperoleh luas tiap kelas yaitu kelas perairan dangkal sebesar 44,8 Ha, kelas darat 33,5 Ha, dan kelas perairan dalam sebesar 27,7 Ha, dari luas keseluruhan lokasi penelitian sebesar $106 \mathrm{Ha}$.

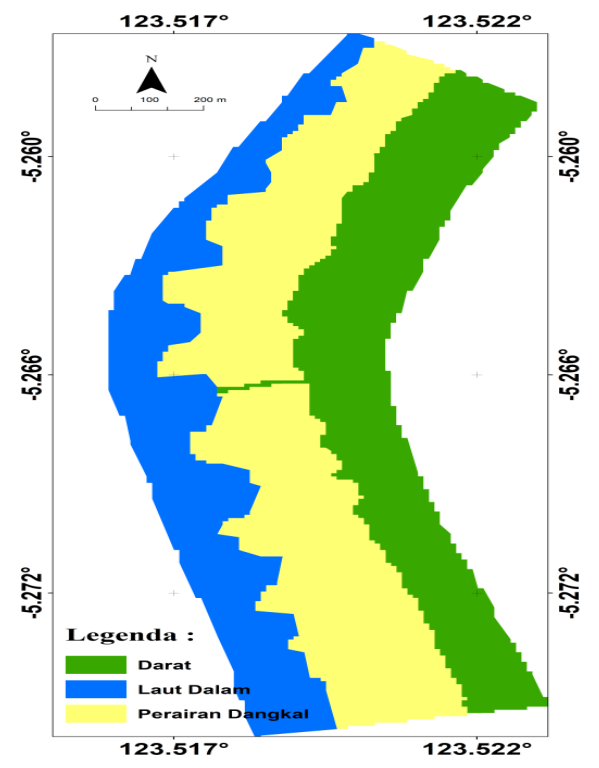

Gambar 4. Hasil klasifikasi level 1 (reef level) yang membagi daerah penelitian kedalam tiga kelas yaitu darat, perairan dangkal, dan laut dalam.

\subsubsection{Klasifikasi Habitat Bentik (Level 2)}

Kelas perairan dangkal pada level 1 kemudian disegmentasi ulang pada level 2 dengan penerapan optimasi skala segmentasi. Objek atau segmen yang dihasilkan selanjutnya diklasifikasi dengan klasifikasi terbimbing menggunakan beberapa algoritma machine learning seperti algoritma SVM, DT, Bayesian, dan KNN dengan menggunakan data skema klasifikasi habitat bentik perairan dangkal sebagai input thematic layer yang telah dibuat sebelumnya berdasarkan pengamatan langsung di lapangan. Input fitur yang digunakan pada proses klasifikasi level 2 yaitu nilai layer (mean dan standar deviasi) dari semua band sinar tampak serta hasil dari tiga komposisi pasangan band DII.

Hasil optimasi skala segmentasi (Gambar 5) diperoleh nilai akurasi tertinggi pada algoritma SVM dan optimum pada skala segmentasi 2 baik pada hasil klasifikasi 12 kelas dan 9 kelas habitat bentik dengan nilai akurasi keseluruhan diperoleh masingmasing sebesar $60,4 \%$ dan $64,1 \%$. Nilai akurasi terendah diperoleh sebesar 29,0\% pada skala segmentasi 1 dan 1,5 dengan algoritma DT untuk hasil klasifikasi 12 kelas dan $32,8 \%$ pada skala segmentasi 1,5 dengan algoritma DT untuk hasil klasifikasi 9 kelas habitat bentik.

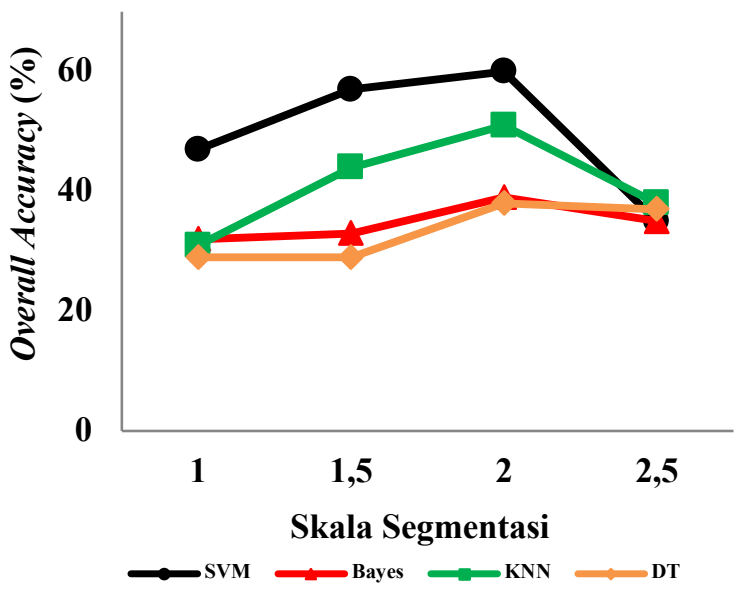




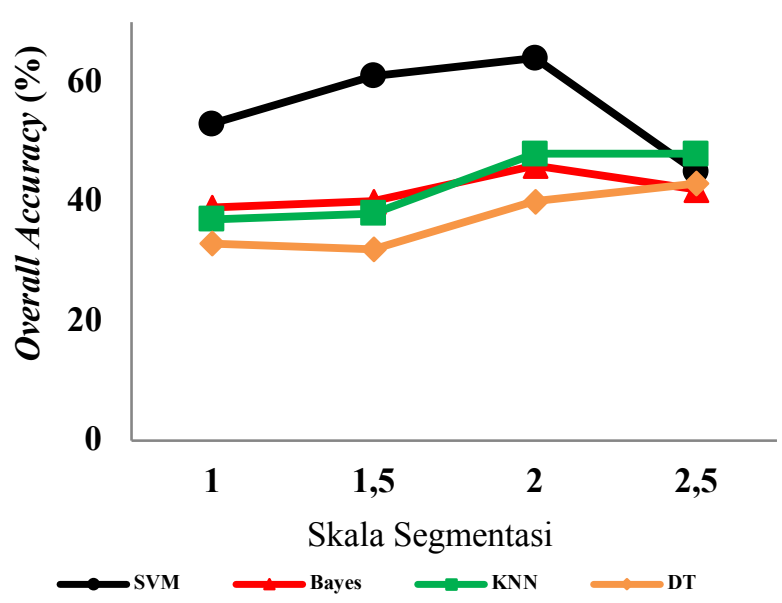

Gambar 5. Hasil Akurasi 12 kelas (atas) dan 9 kelas (bawah) habitat bentik pada tiap algoritma yang digunakan.

Berdasarkan hasil optimasi skala segmentasi dengan penerapan beberapa algoritma klasifikasi, terlihat dengan jelas bahwa algoritma SVM menghasilkan akurasi keseluruhan tertinggi dibandingkan dengan algoritma klasifikasi lainnya. Hal ini sesuai dengan hasil penelitian Wahiddin et al. (2015) yang memetakan habitat bentik terumbu karang dengan menggunakan beberapa algoritma kalasifikasi yaitu algoritma SVM, DT, Bayesian, KNN, random tree (RT) dan dari hasil penelitiannya merekomendasikan untuk menggunakan metode berbasis objek (OBIA) dengan menerapkan algoritma klasifikasi SVM, karena menghasilkan nilai akurasi keseluruhan tertinggi dibandingkan dengan algoritma klasifikasi lainnya yaitu sebesar $73 \%$ pada 7 kelas habitat bentik. Kondraju et al. (2013) juga memetakan jabitat bentik dengan beberapa algoritma klasifikasi yaitu MLC (maximum likelihood), SAM (spectral angular mapper), SID (spectral information divergence) serta SVM, dan menghasilkan nilai akurasi optimum pada penerapan algoritma SVM dengan nilai akurasi sebesar $95,97 \%$ pada 4 kelas habitat bentik. Menurut Mountrakis et al. (2011) algoritma SVM dalam bidang penginderaan jauh memiliki kemampuan yang baik untuk menangani data dengan jumlah yang sedikit dan dapat menghasilkan akurasi yang lebih baik dibandingkan dengan teknik klasifikasi lainnya. Faktor utama yang mempengaruhi peningkatan akurasi dengan menggunakan algoritma mesin pembelajaran (SVM) yaitu kemampuan membedakan objek dengan baik dari penggunaan data dengan ciri probabilitas empiris yang tidak diketahui (Zhang and Xie, 2013).

Hasil klasifikasi dengan menggunakan algoritma SVM pada skala segmentasi 2 menunjukan bahwa terjadi peningkatan akurasi keseluruhan sebesar $3,7 \%$ dari penerapan 12 kelas dan 9 kelas habitat bentik. Hal ini menunjukan bahwa jumlah kelas yang digunakan akan mempengaruhi akurasi hasil klasifikasi, dimana jumlah kelas yang lebih sidikit ( 9 kelas) akan menghasilkan akurasi keseluruhan lebih tinggi dibandingkan dengan penggunaan jumlah kelas yang lebih banyak (12 kelas). Hal ini sesuai dengan hasil penelitian Andrefouet et al. (2003) yang menerapkan beberapa jumlah kelas dengan mengasilkan akurasi keseluruhan yang semakin menurun dengan bertambahnya jumlah kelas yang digunakan yaitu diperoleh akurasi rata-rata 77\% (4-5 kelas), 71\% (7-8 kelas), 56\% (9-11 kelas), dan 53\% (>13 kelas) pada citra Landsat dan IKONOS.

Hasil klasifikasi habitat bentik perairan dangkal (level 2) disajikan pada Gambar 6 untuk hasil klasifikasi 12 kelas dan Gambar 7 untuk hasil klasifikasi 9 kelas habitat bentik.

Berdasarkan hasil klasifikasi habitat bentik pada Gambar 6 dan Gambar 7 terlihat dengan jelas bahwa kelas habitat bentik terdistribusi dengan relatif homogen pada wilayah perairan dangkal. Dari hasil tersebut, kemudian dapat diperoleh luas area masingmasing kelas habitat bentik dengan analisis spasial dari hasil klasifikasi 12 dan 9 kelas habitat bentik perairan dangkal di lokasi penelitian. Gambar 8 menunjukan luas area 12 dan 9 kelas habitat bentik hasil klasifikasi menggunakan algoritma SVM dengan skala segmentasi 2. 


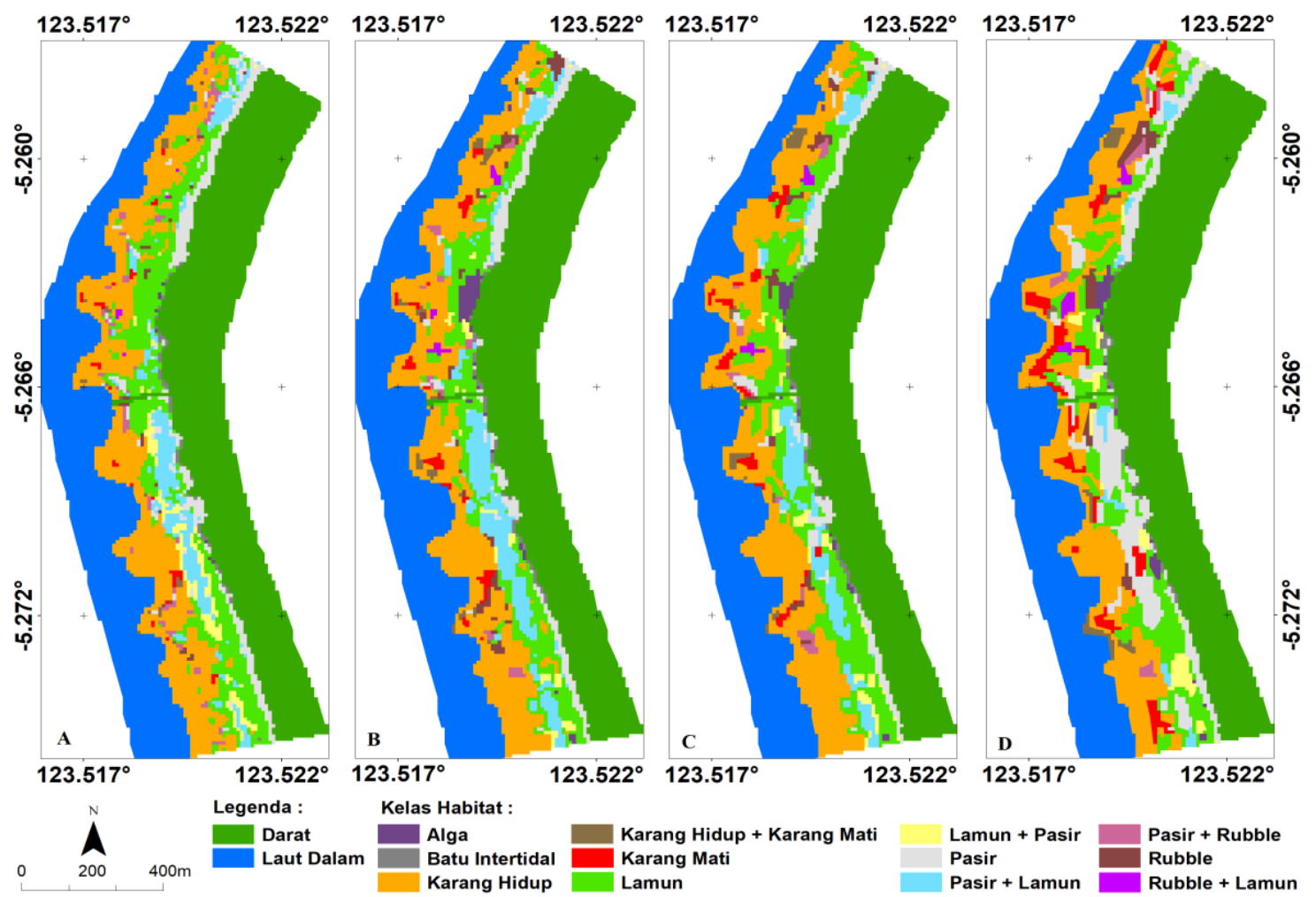

Gambar 6. Hasil klasifikasi 12 kelas habitat bentik menggunakan algoritma SVM; skala segmentasi (A) 1, (B) 1,5, (C) 2, dan (D) 2,5.

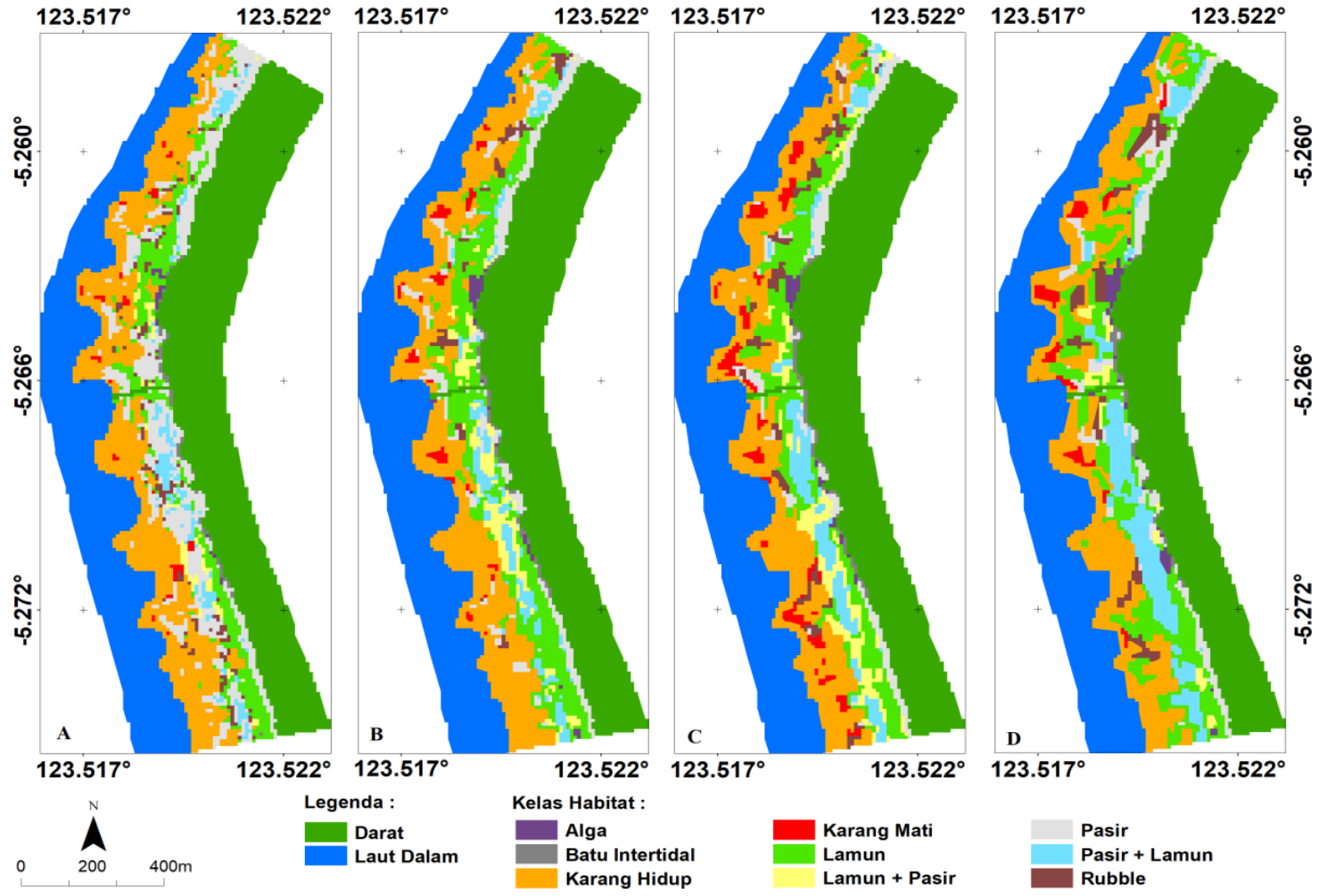

Gambar 7. Hasil klasifikasi 9 kelas habitat bentik menggunakan algoritma SVM; skala segmentasi (A) 1, (B) 1,5, (C) 2, dan (D) 2,5. 


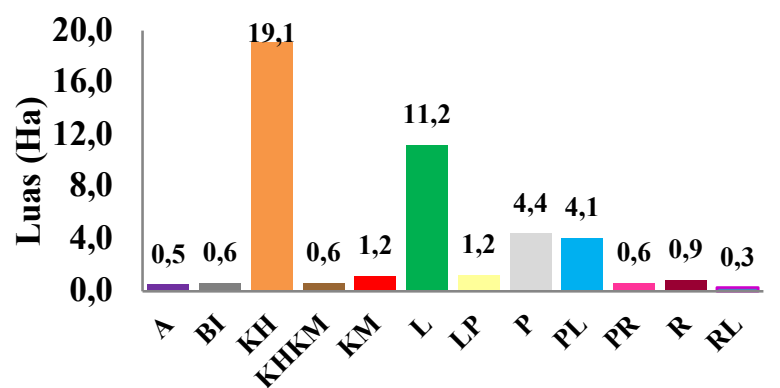

Kelas Habitat Bentik

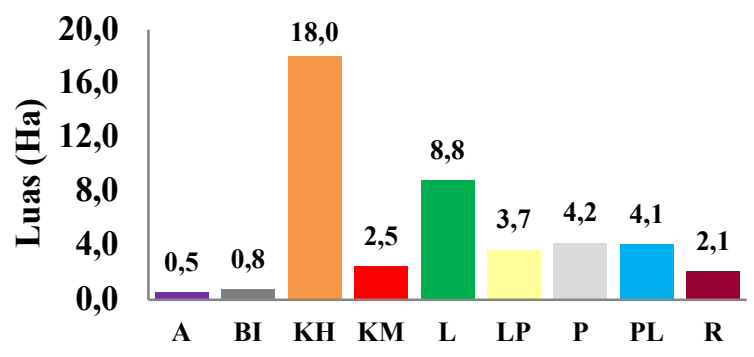

Kelas Habitat Bentik

Gambar 8. Luas kelas habitat bentik hasil klasifikasi 12 kelas (kanan) dan 9 kelas (kiri).

Hasil klasifikasi 12 kelas dan 9 kelas habitat bentik menunjukan bahwa kelas karang hidup $(\mathrm{KH})$ mendominasi area perairan dangkal di lokasi penelitian dengan diperoleh luasan masing-masing sebesar 19,1 Ha dan 18,0 Ha, sedangkan kelas habitat bentik yang memiliki luas area terkecil yaitu didapatkan pada kelas rubble + lamun (RL) sebesar 0,3 Ha pada klasifikasi 12 kelas dan pada klasifikasi 9 kelas didapatkan luasan terkecil pada kelas alga (A) sebesar 0,5 Ha.

Hasil uji akurasi citra Sentinel-2 optimum pada skala segmentasi 2 dengan menggunakan algoritma SVM diperoleh akurasi keseluruhan (OA) sebesar 60,4\% pada 12 kelas dan 64,1\% pada 9 kelas habitat bentik. Green et al. (2000) menyatakan bahwa akurasi pemetaan habitat bentik yang baik atau dapat digunakan apabila peta klasifikasi habitat bentik menghasilkan akurasi keseluruhan (OA) di atas 60\%. Berdasarkan hal tersebut, maka pada penelitian ini peta hasil klasifikasi habitat bentik perairan dangkal dapat digunakan untuk keperluan lebih lanjut.

Saat ini, pemetaan habitat bentik perairan dangkal telah banyak dilakukan dengan menggunakan metode klasifikasi berbasis objek (OBIA) dan penggunaan metode OBIA telah terbukti dapat meningkatkan akurasi pemetaan habitat bentik perairan dangkal. Benfield et al., (2007) memetakan 11 kelas bentik menggunakan citra Quickbird dan Landsat 7 ETM+ dengan algoritma fuzzy logic dan contextual editing menghasilkan akurasi masing-masing sebesar $83,5 \%$ dan $68.7 \%$. Phinn et al., (2011) melakukan pemetaan habitat bentik menggunakan citra Quickbird2 di tiga daerah yang berbeda yaitu di Ngderack Reef (11 kelas), Heron Reef (13 kelas), dan Navakavu Reef (17 kelas) menghasilkan akurasi pemetaan masingmasing $51,6 \%$, 77,9 \%, dan 65,4\%. Zhang et al. (2013) memetakan 12 kelas habitat bentik menggunakan citra AVIRIS (airborne visible/infrared imaging spectrometer) dengan algoritma random forest (RF) menghasilkan akurasi keseluruhan yaitu 75,1-87,9\%. Wahiddin et al., (2015) melakukan pemetaan pada 7 kelas habitat bentik terumbu karang menggunakan Landsat 8 OLI dengan algoritma SVM dan menghasilkan akurasi keseluruhan sebesar 73\%. Anggoro et al., (2017) memetakan 9 kelas habitat bentik menggunakan citra Worldview-2 dengan algoritma SVM dan menghasilkan akurasi keseluruhan sebesar $75 \%$. Dalam penelitian ini dilakukan pemetaan 12 dan 9 kelas habitat bentik menggunakan citra Sentinel-2 dengan algoritma SVM menghasilkan akurasi keseluruhan masing-masing sebesar $60,4 \%$ dan $64,1 \%$. Hasil akurasi penelitian ini lebih rendah dari akurasi penelitian lainnya seperti Wahidin et al. (2015) dan Anggoro et al. (2017) disebabkan oleh: (1) perbedaan penggunaan algoritma klasifikasi, (2) jenis atau kualitas citra yang digunakan, (3) jumlah kelas atau kompleksitas habitat bentik di lokasi kajian, (4) jumlah titik pengamatan lapangan, (5) lokasi dan waktu penelitian 
yang berbeda, dan (6) ukuran dan teknik sampling lapangan yang berbeda. Menurut Anggoro et al. (2017) bahwa perbedaan akurasi pemetaan dapat disebabkan adanya kompleksitas habitat bentik yang sangat tinggi di wilayah kajian.

Umumnya metode klasifikasi yang diterapkan selama ini masih menggunakan metode klasifikasi berbasis piksel yang hanya bertumpu pada aspek spektral saja. Perkembangan metode OBIA saat ini tidak terlepas dari keunggulannya yang dapat menghubungkan antara aspek spektral dan spasial secara bersamaan dalam proses klasifikasi. Selain itu, penggunaan algoritma klasifikasi dalam dunia penginderaan jauh semakin berkembang seperti pemanfaatan algoritma yang berbasis machine learning. Pada penelitian ini, metode OBIA dengan algoritma klasifikasi SVM telah terbukti dapat menghasilkan akurasi pemetaan yang lebih tinggi dibandingkan dengan beberapa algoritma klasifikasi lainnya.

\section{KESIMPULAN}

Habitat bentik perairan dangkal dapat dipetakan dengan baik menggunakan metode klasifikasi berbasis objek (OBIA) dengan algoritma SVM pada citra Sentinel-2 di lokasi kajian. Hasil uji akurasi diperoleh akurasi keseluruhan (OA) untuk 12 kelas dan 9 kelas habitat bentik yaitu masing-masing sebesar $60,4 \%$ dan $64,1 \%$ pada nilai optimum skala segmentasi 2 dengan algoritma SVM. Dari hasil klasifikasi habitat bentik pada klasifikasi 12 dan 9 kelas habitat bentik menunjukan bahwa kelas karang hidup (KH) mendominasi area perairan dangkal di lokasi penelitian dengan diperoleh luasan masing-masing sebesar 19,1 Ha dan 18,0 Ha. Sedangkan kelas habitat bentik yang memiliki luas area terkecil yaitu didapatkan pada kelas rubble + lamun (RL) sebesar 0,3 Ha pada klasifikasi 12 kelas dan pada klasifikasi 9 kelas didapatkan luasan terkecil pada kelas alga (A) sebesar 0,5 Ha.

\section{UCAPAN TERIMA KASIH}

Penelitian ini sebagian dibiayai oleh Direktorat Riset dan Pengabdian Masyarakat Ditjen Penguatan Riset dan Pengembangan Kementerian Riset, Teknologi, dan Pendidikan Tinggi, Republik Indonesia melalui program hibah Penelitian Dasar Unggulan Perguruan Tinggi (PDUPT) dengan surat perjanjian pendanaan penelitian No. 129/SP2H/PTNBH/DRPM/2018 tanggal 1 Februari 2018 dan surat perjanjian penugasan pelaksanaan penelitian No. 1738/IT3.11/PN/2018 tanggal 21 Februari 2018. Penulis mengucapkan terima kasih kepada Dinas Pekerjaan Umum, Tata Ruang dan Pertambangan Kabupaten Wakatobi atas bantuan alat dan fasilitas selama penulis melakukan penelitian, khususnya pada saat proses pengambilan data lapangan. Penulis juga mengucapkan terima kasih kepada reviewer yang telah memberikan masukan untuk meningkatkan kualitas paper ini.

\section{DAFTAR PUSTAKA}

Adji, A.S. 2014. Suitability analysis of multispectral satellite sensors for mapping coral reefs in Indonesia case study: Wakatobi Marine National Park. Mar. Res. Indonesia, 39(2):7378. http://dx.doi.org/10.14203/mri.v3 9i2.87.

Andrefouet, S., P. Kramer, D. Torres-Pulliza, K.E. Joyce, E.J. Hochberg, R. GarzaPérez, P.J. Mumby, B. Riegl, H. Yamano, W.H. White, et al. 2003. Multi-site evaluation of IKONOS data for classification of tropical coral reef environments. Remote Sens. Environ., 88(1-2):128-143. https:// doi.org/10.1016/j.rse.2003.04.005.

Anggoro, A., V.P. Siregar, and S.B. Agus. 2017. Multiscale classification for geomorphic zone and benthic habitats mapping using OBIA method in Pari Island. J. Penginderaan Jauh, 
14(2):89-93. http://dx.doi.org/10.305 36/j.pjpdcd.1017.v14.a2622.

Anggoro, A., V.P. Siregar, and S.B. Agus. 2015. Geomorphic zones mapping of coral reef ecosystem with OBIA method, case study in Pari Island. $J$. Penginderaan Jauh, 12(1):1-12.

Anggoro, A. 2015. Pemetaan zona geomorfologi dan habitat bentik menggunakan citra Wordview-2 dengan metode OBIA di Gugus Pulau Pari. Tesis. Institut Pertanian Bogor. $43 \mathrm{hlm}$.

Balai Taman Nasional Wakatobi [BTNW]. 2009. Informasi Taman Nasional Wakatobi. Bau-Bau, Sulawesi Tenggara. $12 \mathrm{hlm}$.

Benfield, S.L., H.M. Guzman, J.M. Mair, and J.A.T. Young. 2007. Mapping the distribution of coral reefs and associated sublittoral habitats in Pacific Panama: a comparison of optical satellite sensors and classification methodologies. Int. J. Remote Sens., 28(22):5047-5070. https://doi.org/10.1080/01431160701 258062.

Blaschke, T. 2010. Object based image analysis for remote sensing. ISPRS J. Photogramm, 65(1):2-16. https://doi. org/10.1016/j.isprsjprs.2009.06.004.

Bradski, G., A. Kaehler. 2008. Learning opencv: Computer vision with the opencv library. Sebastopol, CA, USA: O'Reilly Media, Inc. 555p.

Congalton, R.G. and K. Green. 2009. Assessing the accuracy of remotely sensed data principles and practices (second edition). CRC Press: Taylor \& Francis Group. France. 183 p.

Coral Reef Rehabilitation and Management Program (COREMAP). 2001. CRITC report: Base line study Wakatobi Sulawesi Tenggara. COREMAP. 132 p.

Green, E., A.J. Edwards, and C. Clark. 2000. Remote sensing handbook for tropical coastal management. Unesco Pub. Paris. 316 p.

Hafizt, M., M.D.M. Manessa, N.S. Adi, and B. Prayudha. 2017. Benthic habitat mapping by combining lyzenga's optical model and relative water depth model in Lintea Island, Southeast Sulawesi. The 5th Geoinformation Science Symposium, IOP Conf. Series: Earth and Environmental Science, 98:012037. https://doi.org/10.1088/17551315/98/1/012037.

Han, J., M. Kamber, and J. Pei. 2012. Data mining: Concepts and techniques (Third edition). Waltham, MA 02451 (USA): Morgan Kaufmann Publishers. 703 p.

Kondraju, T.T., V.R.B. Mandla, R.S. Mahendra, and T.S. Kumar. 2013. Evaluation of various image classification techniques on Landsat to identify coral reefs. Geomatics, Natural Hazards and Risk, 5:173184. http://dx.doi.org/10.1080/1947 5705.2013.802748.

Lyzenga, D.R. 1981. Remote sensing of bottom reflactance and water attenuation parameters in shallow water using aircraft and Landsat data. Int. J. Remote Sens., 2:71-82. https://doi.org/10.1080/01431168108 948342.

Lyzenga, D.R. 1978. Passive remote sensing techniques for mapping water depth and bottom features. Appl. Opt., 17(3):379-383. https://doi.org/10.13 64/AO.17.000379.

Mountrakis, G., J. Im, and C. Ogole. 2011. Support vector machines in remote sensing: A review. ISPRS J. Photogramm., 66(3):247-259. https:// doi.org/10.1016/j.isprsjprs.2010.11.0 01 .

Navulur, K. 2007. Multispectral image analysis using the object-oriented paradigm. CRC Press: Taylor \& Francis Group. France. 165 p. 
Phinn, S.R., C.M. Roelfsema, and P.J. Mumby. 2011. Multi-scale, objectbased image analysis for mapping geomorphic and ecological zones on coral reefs. Int. J. Remote Sensing, 33:3768-3797. http://dx.doi.org/10.10 80/01431161.2011.633122.

Purbani, D., Yulius, M. Ramdhan, T. Arifin, H.L. Salim, and N. Novianti. 2014. Beach characteristics of Wakatobi National Park to support marine ecotourism: A case study of Wangiwangi Island. Depik, 3(2):137-145. https://doi.org/10.13170/depik.3.2.15 39.

Roelfsema, C. and S. Phinn. 2008. Evaluating eight field and remote sensing approaches for mapping the benthos of three different coral reef environments in Fiji. In: Frouin, R.J. et al. (eds.). Proc. SPIE, Remote sensing of inland, coastal, and oceanic waters. 7150:71500F. https:// doi.org/10.1117/12.804806.

Selamat, M.B., I. Jaya, V.P. Siregar, dan T. Hestirianoto. 2012a. Aplikasi citra quickbird untuk pemetaan 3D substrat dasar di gusung karang. J. Ilmiah Geomatika, 8(2):95-106.

Selamat, M.B., I. Jaya, V.P. Siregar, and T. Hestirianoto. 2012b. Geomorphology zonation and column correction for bottom substrat mapping using quickbird image. J. Teknologi Perikanan dan Kelautan, 2(2):17-25. http://dx.doi.org/10.24319/jtpk.3.1725

Siregar, V.P., S. Wouthuyzen, A. Sunuddin, A. Anggoro, dan A.A. Mustika. 2013. Pemetaan habitat dasar dan estimasi stok ikan terumbu dengan citra satelit resolusi tinggi. J. Ilmu dan Teknologi Kelautan Tropis, 5:453-463. http://dx. doi.org/10.29244/jitkt.v5i2. 7573.

Siregar, V.P. 2010. pemetaan substrat dasar perairan dangkal karang congkak dan lebar Kepulauan Seribu menggunakan citra satelit quick bird.
J. Ilmu dan Teknologi Kelautan Tropis, 2(1):19-30. http://dx.doi.org /10.29244/jitkt.v2i1.7860.

Supriatna, J. 2008. Melestarikan alam Indonesia. Yayasan Obor Indonesia. Jakarta. $482 \mathrm{hlm}$.

Suyarso, dan A. Budiyanto. 2008. Studi baseline terumbu karang di lokasi DPL Kabupaten Wakatobi. COREMAP II (Coral Reef Rehabilitation and Management Program)-LIPI. Jakarta. $107 \mathrm{hlm}$.

Trimble. 2014. Ecognition developer: user guide. Trimble Germany $\mathrm{GmbH}$. Munchen, Germany. 262 p.

Tzotsos, A. 2006. A support vector machine approach for object based image analysis. 2006. In: 1st International Conference on Object-based Image Analysis, OBIA, Salzburg, Austria, 45 July. 6 p.

Wahiddin, N., V.P. Siregar, B. Nababan, I. Jaya, and S. Wouthuyzend. 2015. Object-based image analysis for coral reef benthic habitat mapping with several classification algorithms. Procedia Environmental Sciences, 24:222-227. https://doi.org/10.1016/ j.proenv.2015.03.029.

Wahiddin, N. 2015. Klasifikasi ekosistem terumbu karang berbasis objek dan piksel di Pulau Morotai. Disertasi. Institut Pertanian Bogor. Bogor. 102hlm.

Wahiddin, N., V.P. Siregar, B. Nababan, I. Jaya, dan S. Wouthuyzend. 2014. Deteksi perubahan habitat terumbu karang menggunakan citra Landsat di pulau morotai provinsi maluku utara. J. Ilmu dan Teknologi Kelautan Tropis, 6(2):507-524. http://dx.doi. org/10.29244/jitkt.v6i2.9026.

Wang, L., W.P. Sousa, and P. Gong. 2004. Integration of object-based and pixelbased classification for mapping mangroves with IKONOS imagery. Int. J. Remote Sens., 25(24):56555668 . 
http://dx.doi.org/10.1080/014311602 331291215.

Wei, W., X. Chen, A. Ma. 2005. Objectoriented information extraction and application in high-resolution remote sensing image. IEEE International Geoscience and Remote Sensing Symposium. 8:3803-3807. http://doi. org/10.1109/IGARSS.2005.1525737.

Wilson, J.R., R.L. Ardiwijaya, and R. Prasetia. 2012. A study of the impact of the 2010 coral bleaching event on coral communities in Wakatobi National Park. The Nature Conservancy. 23 p.

Yulius, N. Novianti, T. Arifin, H.L. Salim, M. Ramdhan, and D. Purbani. 2015. Coral reef spatial distribution in Wangi-wangi island waters, Wakatobi. J. Ilmu dan Teknologi Kelautan Tropis, 7(1):59-69. http:// dx.doi.org/10.29244/jitkt.v7i1.9774.
Zhang, C. 2014. Applying data fusion techniques for benthic habitat mapping. ISPRS J. of Photogrammetry and Remote Sensing, 104:213-223. http://dx.doi.org/10. 1016/j.isprsjprs.2014.06.005.

Zhang, C., D. Selch, Z. Xie, C. Roberts, H. Cooper, and G. Chen. 2013. Objectbased benthic habitat mapping in the Florida Keys from hyperspectral imagery. Estuar. Coast. Shelf S., 134:88-97. http://dx.doi.org/10.1016/ j.ecss.2013.09.018.

Zhang, C. and Z. Xie. 2013. Object-based vegetation mapping in the Kissimmee river watershed using hymap data and machine learning techniques. Wetlands, 33(2):233-244. https://doi. org/10.1007/s13157-012-0373-x.

$\begin{array}{ll}\text { Diterima } & : 23 \text { April } 2018 \\ \text { Direview } & : 05 \text { Mei } 2018 \\ \text { Disetujui } & : \text { :05 Juli } 2018\end{array}$

